\title{
Serum Levels of Lactate Dehydrogenase and Alkaline Phosphatase Enzymes in Colorectal Cancer
}

\author{
Batool Hassan Al-Ghurabi ${ }^{1 *}$, Abeer Khalid Yaseen ${ }^{1}$ and Mohammed Imran \\ Hamzah² \\ ${ }^{1}$ Department of Basic Science, College of Dentistry, University of Baghdad, Iraq. ${ }^{2}$ Department of Biochemistry, \\ Medical College, Al-Nahrain University, Iraq.
}

\begin{abstract}
Colorectal cancer (CRC) remains one of the main public health problems throughout the world. It has recently been observed that both of lactate dehydrogenase (LDH) and alkaline phosphatase (ALP) enzymes play critical role in cancer expansion. Current study was enrolled for investigating serum levels of LDH and ALP before and after surgery, as well as to assess if whether association of these enzymes with the histological grades of CRC. By using colorimetric method the activity LDH and ALP were determined in serum of 50 CRC patients before surgery, and in 30 patients after surgical compared with $\mathbf{3 0}$ healthy controls. The levels of LDH and ALP were increase in patients group before surgical treatment $(p<0.001)$ than that in control group. Further, significant differences were found in the mean of serum enzymes after surgery in $\mathbf{3 0}$ patients, also mean serum levels of these enzymes increased in patients with advanced stages of tumor. These finding suggest that serum levels of LDH and ALP appears to be of some prognostic value in CRC.
\end{abstract}

Keywords: Colorectal cancer, ALP, LDH.

*Correspondence: batoolmms@yahoo.com

(Received: 04 February 2019; accepted: 07 March 2019)

Citation: Batool Hassan Al-Ghurabi, Abeer Khalid Yaseen and Mohammed Imran Hamzah, Serum Levels of Lactate Dehydrogenase and Alkaline Phosphatase Enzymes in Colorectal Cancer, J Pure Appl Microbiol., 2019; 13(1):475-479 doi: 10.22207/JPAM.13.1.53

(c) The Author(s) 2019. Open Access. This article is distributed under the terms of the Creative Commons Attribution 4.0 International License which permits unrestricted use, sharing, distribution, and reproduction in any medium, provided you give appropriate credit to the original author(s) and the source, provide a link to the Creative Commons license, and indicate if changes were made. 


\section{INTRODUCTION}

Colorectal cancer is among the most common malignancies and leading causes of cancer related deaths in developed countries. CRC is evaluated as the third most common cancer overall, it accounts for nearly $10 \%$ of all cancers (Siegel and Jemal, 2015). Early detection of cancer can be potentially cured through surgery especially, when the tumor is very small and has not metastasized. In view of this, there is need for simple biochemical investigations, for early detection such as the use of tumor markers which include some enzymes (Chougule et al., 2008). It is well known that converting of normal cells into malignant cells often leads to synthesis of abnormal serum enzyme, till before changes in tumor morphology. Since, study of enzymes has received more interest, Fantin et al., reported that LDH was closely associated with analysis of glucose and mitochondrial shortage that is demanded for tumor conservation (Fantin et al., 2006), Stinghen and colleagues suggested that ALP could be considered as a tumor marker (Stinghen et al., 2006).

Alkaline phosphatase is a hydrolase enzyme which accountable to remove phosphate groups. LDH plays necessary part in the transformation of pyruvate to lactate. Each of them has been noticed to have prognostic value in many tumors. Based on prior researches with various types of malignancies, increase in ALP or LDH could suggest a heavy tumor burden and tumor spread. Increase ALP level was suggested to be associated with poor prognosis in various kinds of tumors (Maisano et al., 2011; Sonpavde et al., 2012; Xie et al., 2014; Wei et al., 2016). Similarly, $\mathrm{LDH}$ released as a result of cell damage. It has been demonstrated in variety of cancers that include liver; non-Hodgkin's lymphoma, acute leukemia, breast colon, stomach and lung cancers. The serum LDH level has been found to correlate with tumor mass in solid tumors and provide a prognostic indicator of disease progression (Wei et al., 2014; Sagman et al., 1991; Yamada et al., 2011). Present work was enrolled to estimate the serum levels of $\mathrm{LDH}$ and ALP before and after surgery, as well as to assess the association between serum LDH and ALP with the histological grades of CRC.

\section{MATERIALS AND METHODS Subjects}

This study involved a total of 50 patients of CRC comprised of 31 males and 19 females, the patients were clinically and histological diagnosed. A well 30 normal healthy persons, age and sex matched with the study group were selected as controls.

\section{Sample collection}

Four $\mathrm{ml}$ of blood was collected from each subject (patients and controls) and put in sterile tubes, then centrifuged and serum separated, aliquated and stored at $-20^{\circ} \mathrm{C}$ until used.

\section{Detection of enzymes}

Serum enzymes were determined by using commercially available kits ALP and LDH (Human com., Germany). The assay was carried out using colorimetric method.

\section{Statistical Analysis}

Statistical analyses were done using SPSS v19. The serum LDH and ALP were expressed as mean $\pm \mathrm{SE}$, the significance of differences in mean was estimated by the student's t-test. Analyses where the $P$-value was $<0.05$ were considered to be statistically significant.

\section{RESULTS}

The present study showed that the age of CRC patients ranged between (20-74) years with a mean age of $(49.8 \pm 1.5)$ years. For healthy control the age range was (20-70) years, with a mean age of $(45.9 \pm 1.9)$ years, however, there are no significant differences ( $p>0.05)$ in age and gender between patients and control groups.

Table 1. The difference in mean levels of serum enzymes $(U / L)$ concentration between patients and controls groups

\begin{tabular}{lccl}
\hline $\begin{array}{l}\text { Serum } \\
\text { Enzymes }\end{array}$ & $\begin{array}{c}\text { CRC } \\
\text { Patients } \\
\mathrm{N}=50\end{array}$ & $\begin{array}{c}\text { Healthy } \\
\text { controls } \\
\mathrm{N}=30\end{array}$ & $\begin{array}{c}P \text {-value } \\
\text { (t-test) }\end{array}$ \\
\hline $\begin{array}{l}\text { Serum LDH } \\
\text { Range }\end{array}$ & $94-218$ & $90-190$ & \\
Mean \pm SE & $161.9 \pm 6.36$ & $119 \pm 5.57$ & $<0.002^{* *}$ \\
Serum ALP & & & \\
Range & $50-180$ & $30-85$ & \\
Mean \pm SE & $106.2 \pm 6.28$ & $59.4 \pm 2.3$ & $<0.001^{* *}$ \\
\hline
\end{tabular}

** highly significant; SE: standard error 
Table 2. The difference in mean levels of serum enzymes (U/L) concentration among different stage of tumor in patients

\begin{tabular}{lcccc}
\hline $\begin{array}{l}\text { Serum } \\
\text { Enzymes }\end{array}$ & $\begin{array}{c}\text { Stage } \\
\text { II } \\
\mathrm{N}=25\end{array}$ & $\begin{array}{c}\text { Stage } \\
\text { III } \\
\mathrm{N}=15\end{array}$ & $\begin{array}{c}\text { Stage } \\
\text { IV } \\
\mathrm{N}=10\end{array}$ & $\begin{array}{c}P \text {-value } \\
\text { (ANOVA) }\end{array}$ \\
\hline $\begin{array}{l}\text { Serum LDH } \\
\text { Mean }\end{array}$ & 124.9 & 195.1 & 207.1 & $<0.001$ \\
SD & 30.96 & 11.07 & 7.40 & \\
$\begin{array}{l}\text { Serum ALP } \\
\text { Mean }\end{array}$ & 75.3 & 112.3 & 168.5 & $<0.001$ \\
SD & 24.91 & 31.69 & 14.50 & \\
\hline
\end{tabular}

Table 3. The difference in mean levels of serum enzymes $(U / L)$ concentration between preoperative group and postoperative group of patients

\begin{tabular}{lccc}
\hline Serum & Before & After & T-test \\
Enzymes & Surgery & Surgery & \\
& $\mathrm{N}=30$ & $\mathrm{~N}=30$ & \\
\hline
\end{tabular}

\begin{tabular}{lccc}
\hline Serum LDH & & & \\
Range & $94-210$ & $79-185$ & \\
Mean \pm SE & $163.6 \pm 8.34$ & $129 \pm 7.06$ & $<0.003$ \\
Serum ALP & & & \\
Range & $50-175$ & $49-150$ & \\
Mean \pm SE & $107.8 \pm 7.84$ & $80.0 \pm 4.55$ & $<0.001$ \\
\hline
\end{tabular}

The present study revealed significant increase in the values of both enzymes among patients group (161.9 $\pm 6.36 \mathrm{U} / \mathrm{L}$ and106.2 \pm 6.28 $\mathrm{U} / \mathrm{L})$ as compared to controls group (119 \pm 5.57 $\mathrm{U} / \mathrm{L}$ and $59.4 \pm 2.3 \mathrm{U} / \mathrm{L}$ ) with $\mathrm{P}<0.01$, table (1). In addition, table (2) pointed out to positive association between serum enzymes level and the progression of the cancer $\mathrm{P}<0.001$. Since table (2) showed that serum level of LDH and ALP in CRC patients increased with advance stage. On the other hand, there are significant decrease $(P<0.05)$ in mean serum levels of these enzymes postoperatively $(129 \pm 7.06 \mathrm{U} / \mathrm{L}$ and $80.0 \pm 4.55 \mathrm{U} / \mathrm{L}$ ) when compared to their levels preoperatively $(163.6 \pm 8.34 \mathrm{U} / \mathrm{L}$ and $107.8 \pm 7.84$ $\mathrm{U} / \mathrm{L}$ ) in patients group, as clearly observed in table (3). Finally, we found positive correlation between two enzymes but statistically non significant $(r=$ $0.2304, P=0.221$ ), as shown in table (4).
Table 4. Correlation between LDH and ALP in CRC patients

\begin{tabular}{lcc}
\hline Serum enzymes & Correlation $r$ & $p$-value \\
\hline LDH \& ALP & 0.2304 & 0.221 \\
\hline
\end{tabular}

\section{DISCUSSION}

Cancers are composed of cell clones capable of rapid propagation. Tumor development has a unrivaled metabolic features include changes in several molecular indices in the serum, involving enzymes, proteins, and hormones. The function of enzymes especially LDH and ALP in carcinogenesis in associated to disease activity have shown useful in estimating the range and prediction of malignant tumor (Yadav, 2017).

The current results are found significant height in serum levels of LDH and ALP in patients with CRC when compared to controls, which is in accordance with the observations of the previous researchers (Ojo et al., 2016; Saif et al., 2005; Connell et al., 2017). Ojo and colleagues showed significantly increasing values of serum LDH and ALP enzymes in CRC compared to controls, and reported that the associations between high activities of these enzymes and risk of developing cancer could be used as tumor markers in the prognosis, diagnosis and management of cancer (Ojo et al., 2016). Consistently, Connell and workers showed that elevated serum levels of LDH at baseline significantly correlate with a poor prognosis in unresectable colorectal liver metastases (Connell et al., 2017). The increase in ALP level in Gl cancer patients may probably due to destruction of tissues facilitating the leakage of enzyme and their appearance in blood circulation (Yadav, 2017). However; in cancer patients, elevated ALP may indicate that cancer has spread to bones or that liver damage is possible due to chemotherapy drugs that affected the bile excretion (Nigam et al., 2005). As well this result was in agreement with the previous study done by Sandhya who reported high activity LDH in malignant tissues and in serum of patients with a variety of epithelial tumors. The elevated LDH activity observed might be due to the fact that tumor cells depend on anaerobic respiration 
for the transformation of glucose to lactate on a par with under oxygen-sufficient circumstances and this condition of fermentative glycolysis is stimulated by LDH (Sandhya et al., 2004).

Other important results in our study are that the mean value of LDH and ALP in patients increased with advance stage as well as the significant reduction in the levels of serum enzymes postoperatively as compared to their levels at baseline

These observations are comparable to other previous results (Yadav, 2017and Harmenberg et al., 1989) in their studies also noted an association between tumor progressions of colorectal carcinoma and elevated serum ALP enzyme. Hung et al., 2017 observed that the elevated preoperative ALP levels was not only associated with liver disease, but it was also related with advanced tumor status, and indicated a poor survival in colon and rectal cancer patients. Noteworthy, Yadav and colleagues reported that the levels of LDH and ALP decreased after the treatments of colon cancer patients. The magnitude of these markers reduction may, however, reflect the degree of success of treatment of colorectal carcinoma (Yadav, 2017).

Both of LDH and ALP are indicators of tumor spread and evolution, and they have been assured as prognostic biomarkers in several types of tumors (Faloppi et al., 2015 and Wei et al., 2015), yet, the correlation between LDH and ALP in colon cancer has not been studied previously, particularly the prediction importance of their collection. In this work, we estimate the association between these two markers and observed non significant positive correlation between them.

\section{CONCLUSION}

In conclusions the current finding suggests that serum levels of LDH and ALP appears to be of some prognostic value in CRC.

\section{ACKNOWLEDGEMENTS}

None

\section{CONFLICTS OF INTEREST}

The author declares that there are no conflict of interest.

\section{REFERENCES}

1. Siegel RL, Miller KD, Jemal A. Cancer statistics. A Cancer Journal for Clinicians, 2015; 65(1): 5-29

2. Chougule A, Hussain S and Dwaraka PA. Prognostic and diagnostic values of Pseudocholinesterase, serum aspartate transaminase and serum alanine transaminase in malignancies treated by radiotherapy. Journal of Cancer research and Therapeutics, 2008; 4(1): 21-25.

3. Fantin VR, St-Pierre J, Leder P. Attenuation of LDH-A expression uncovers a link between glycolysis, mitochondrial physiology, and tumor maintenance. Cancer Cell, 2006; 9:425-434.

4. Stinghen ST, Moura JF, Zancanella $P$ et al. Specific immunoassays for placental alkaline phosphatase as a tumor marker. Journal of Biomedcal and Biotechnology, 2006; 2006: 56087.

5. Maisano R, Azzarello D, Del Medico P, Maisano M, Bottari M, Egitto $G$, et al. Alkaline phosphatase levels as a prognostic factor in metastatic colorectal cancer treated with the FOLFOX 4 regimen: a monoinstitutional retrospective study. Tumori journal, 2011; 97: 39-42.

6. Xie Y, Wei ZB, Duan XW. Prognostic value of pretreatment serum alkaline phosphatase in nasopharyngeal carcinoma. Asian Pacific journal of cancer prevention, 2014; 15: 3547-53.

7. Sonpavde G, Pond GR, Berry WR, de Wit R, Armstrong AJ, Eisenberger MA, et al. Serum alkaline phosphatase changes predict survival independent of PSA changes in men with castration-resistant prostate cancer and bone metastasis receiving chemotherapy. Urologic oncology, 2012; 30: 607-13.

8. Wei XL, Zhang DS, He MM, Jin Y, Wang DS, Zhou YX, et al. The predictive value of alkaline phosphatase and lactate dehydrogenase for overall survival in patients with esophageal squamous cell carcinoma. Tumour biology : The Journal of the International Society for Onco-developmental Biology and Medicine, 2016; 37 : 1879-87.

9. Wei Z, Zeng X, Xu J, Duan X, Xie Y. Prognostic value of pretreatment serum levels of lactate dehydrogenase in nonmetastatic nasopha-ryngeal carcinoma: singlesite analysis of 601 patients in a highly endemic area. OncoTargets and therapy, 2014; 7: 739-49.

10. Sagman U, Feld R, Evans WK, Warr D, Shepherd FA, Payne D, et al. The prognostic significance of pretreatment serum lactate dehydrogenase in patients with small-cell lung cancer. Journal of clinical oncology. Official journal of the American Society of Clinical Oncology, 1991; 9: 954-61.

11. Yamada Y, Nakamura K, Aoki S, Tobiume M, Zennami K, Kato Y, et al. Lactate dehydrogenase, Gleason score and HER-2 over expression are significant prognostic factors for M1b prostate cancer. Oncology reports, 2011; 25: 937-44.

12. Yadav P. Significance of Serum Alkaline Phosphate and Lactate Dehydrogenase on Diagnosis and Prognosis of Gastrointestinal Cancer. International Journal of Innovative Research in Medical Science, 2017; 2(5). 
13. Ojo O, Asaolu M, Akinlua, Oyeyemi A, Atiba A. Serum Marker Enzymes Activities in Cancer Patients. Journal of Chemistry and Biochemistry, 2016; 4(2): 15-21

14. Saif W, Alexander D, WICOX C. Serum Alkaline Phosphatase level as a Prognostic Tool in Colorectal Cancer: A study of 105 patients. Journal of Applied Research, 2005; 5(1): 88-95.

15 Connell L, Boucher T, Chou J, Capanu M, Maldonado $\mathrm{S}$, Kemeny N. Relevance of CEA and LDH in relation to KRAS status in patients with unresectable colorectal liver metastases Journal of Surgical Oncology, 2017; 115(4): 480-487.

16. Nigam PK, Jain A, Goyal P, Chitra R. Role of heat stable fraction of alkaline phosphatase as an adjunct to ca 125 in monitoring patients of epithelial ovarian carcinoma. Indian Journal of Clinical Biochemistry, 2005; 20(2): 43-47.

17. Sandhya M, Sharma DC and Praveen S. Studies of biochemical parameters in Breast Cancer with and without Metastasis. Indian Journal of Clinical
Biochemistry, 2004; 19(1): 71-75.

18. Harmenberg U, Fordin JE, Ljungdahi S, Mellsted H. Significance of alkaline isoenzymes in the monitoring of patients with colorectal carcinoma. Tumor Biology, 1989; 10(5): 225-31.

19. Hung H, Chen J, ChienY, Tang R, Hsieh P, Wen $S$, You Y, You J, Chiang J. Preoperative alkaline phosphatase elevation was associated with poor survival in colorectal cancer patients. International Journal of Colorectal Disease, 2017; 32(12):1775-1778.

20. Faloppi L, Bianconi M, Giampieri R, et al. The value of lactate dehydrogenase serum levels as a prognostic and predictive factor for advanced pancreatic cancer patients receiving sorafenib. Oncotarget, 2015; 6: 35087-35094.

21. Wei XL, Zhang DS, He M, et al. The predictive value of alkaline phosphatase and lactate dehydro-genase for overall survival in patients with esophageal squamous cell carcinoma. Tumour Biology, 2015; 37(2): 18791887. 